\title{
WYZWANIA DLA OCHRONY PRAW LUDNOŚCI RDZENNEJ W PAPUI ZACHODNIEJ
}

Po zmianie ustrojowej, która dokonała się po obaleniu reżimu prezydenta Suharto w 1998 r., Republice Indonezji udało się osiagnnąc stabilizację polityczną we wszystkich prowincjach państwa z wyjątkiem Papui i Papui Zachodniej ${ }^{1}$. Trwający tam konflikt zbrojny, który rozgrywa się pomiędzy władzami Indonezji a ludnością papuaska, ma podłoże historyczne i dotyczy ochrony praw ludności rdzennej. Ponadto nacjonaliści papuascy ${ }^{2}$ domagają się prawa do samostanowienia, by stworzyć własne państwo ${ }^{3}$. W 2001 r. władze Indonezji przyznały obu prowincjom specjalną autonomię (na mocy ustawy o specjalnej autonomii dla prowincji Papui nr 21 z 2001 r., zwanej dalej ustawą o autonomii) ${ }^{4}$, jednakże nacjonaliści papuascy twierdza, że zawarte w niej prawa nie są przestrzegane przez kolejne rządy Indonezji. Rząd Indonezji utrzymuje, że realizuje politykę zgodną z zasadami demokracji, w której prawa ludności rdzennej są chronione ${ }^{5}$. Celem artykułu jest prezentacja stanowisk skonfliktowanych stron poprzez ukazanie wyzwań politycznych, prawnych i ekonomicznych, przed jakimi stoi rzą indonezyjski w prowincjach: Papua i Papua Zachodnia. Podjęto próbę udowodnienia tezy, że rząd indonezyjski pod wpływem presji społeczności międzynarodowej podjął działania w celu implementacji praw rdzennej ludności papuaskiej.

1 J. Braitwaite, V. Braitwaite, M. Cookson, L. Dunn, Anomie and Violence. Non-truth and reconciliation in Indonesian peacebuilding, Canberra 2010, s. 1.

2 Tym pojęciem określam aktywistów papuaskich, którzy uważają, że Papuasi stanowią oddzielny naród.

3 C. Webb-Gannon, Merdeka in West Papua: peace, justice and political independence, „Anthropologica" 2014, vol. 56, issue 2, s. 353 .

4 Dynamics of conflict and displacement in Papua, Indonesia. A collection of papers developed in conjunction with a one-day workshop held on the $26^{\text {th }}$ October 2006 at St. Antony's College, Oxford, ed. E.L.E. Hedman, RSC Working Paper no. 42, Oxford 2007, s. 6, https://www.academia.edu/1975114/Dynamics_of_Conflict_and_Displacement_in_Papua_Indonesia (dostęp: 17.09.2019).

5 Report A/HRC/WG.6/27/IDN/1 Human Rights Council Working Group on the Universal Periodic Review Twenty-seventh session 1-12 May 2017, pkt 15, 86, http://humanrightspapua.org/images/docs/Indonesia_natioanlreport_3rdUPRcycle.pdf (dostęp: 9.09.2019). 


\section{Wyzwania polityczne}

Papuasi są rdzennymi mieszkańcami prowincji Papua i Papua Zachodnia, które w czasach Holenderskich Indii Wschodnich były znane jako Zachodnia Nowa Gwinea, a po przyłączeniu do Indonezji zostały nazwane Zachodnim Irianem ${ }^{6}$. W 2003 r. władze Indonezji podzieliły to terytorium na dwie prowincje: Papuę i Zachodni Irian, który 4 lata później został nazwany Papuą Zachodnią ${ }^{7}$ W artykule obydwie prowincje są określane popularną nazwą Papua Zachodnia, której używają nacjonaliści papuascy ${ }^{8}$. Odrębność etniczna jest ich argumentem w żądaniach, by ustanowiono samodzielne państwo. Podkreślają swoją odmienność kulturową od pozostałych społeczności archipelagu wywodzących się z terenów Azji, co wiąże się z melanezyjskim pochodzeniem mieszkańców Zachodniej Papui9.

Oprócz odrębności etnicznej papuaskich nacjonalistów łączy wspólna historia, która, jak twierdzą, opiera się na krzywdzie, wyzysku i dyskryminacji ze strony indonezyjskiego państwa, postrzeganego przez nich jako okupant Zachodniej Papui ${ }^{10}$. Agus Sumule, przedstawiciel stowarzyszenia The Coalition of Lawyers for Truth and Justice of West Papuan People ${ }^{11}$ działającego na rzecz Wolnej Papui stwierdził, że Papuasi uznają akt samostanowienia z 1969 r. zwany Aktem Wolnego Wyboru za nielegalny ${ }^{12}$. W ich opinii podważa to również status polityczny Zachodniej Papui jako terytorium przynależnego do Republiki Indonezji. W efekcie Akt Wolnego Wyboru, który usankcjonował przyłączenie Nowej Gwinei do Republiki Indonezji,

6 T.D. Musgrave, An analysis of the 1969 Act of Free Choice in West Papua [w:] Sovereignty, statehood and state responsibility: Essays in honour of James Crawford, eds. C. Chinkin, F. Baetens, Cambridge 2015, s. 209, doi: 10.1017/CBO9781107360075.017 (dostęp: 26.02.2019).

7 Dynamics of conflict..., s. 6.

8 S. Lawson, West Papua, Indonesia and the Melanesian Spearbead Group: competing logics in regional and international politics, „Australian Journal of International Affairs” 2016, vol. 70, issue 5, s. 15, http://dx.doi.org/10.1080/10357718.2015.1119231 (dostęp: 4.10.2019). Papuasi w manifeście politycznym użyli nazwy Papua Zachodnia do określenia Holenderskiej Nowej Gwinei. R. Chauvel, Constructing Papuan nationalism: History, ethnicity, and adaption, series: Policy Studies 14, Washington 2005, s. 22, https://scholarspace.manoa.hawaii.edu/bitstream/10125/3515/PS014. pdf (dostęp: 4.10.2019).

9 Niektórzy mieszkańcy Moluków i Wschodniej Nusa Tengarry są również pochodzenia melanezyjskiego, ale Papuasi z Papui Zachodniej uważają że nie mają więzów narodowościowych z mieszkańcami wcześniejszego Królestwa Maluków. Zob. S. Lawson, West Papua..., s. 13.

10 Ibidem, s. 2.

11 T. Brent, West Papua. Choosing to act, https://southeastasiaglobe.com/fifty-years-on-indonesia-tightens-its-grip-on-papua/ (dostęp: 24.10.2019).

12 O. Mote, Special Autonomy Issue, https://www.etan.org/issues/wpapua/1207spaut.htm (dostęp: 30.04.2019). 
stał się dla nich symbolem niesprawiedliwości głównie z powodu kontrowersji powstałych wokól jego przeprowadzenia ${ }^{13}$.

Zgodnie z założeniami przyjętymi w porozumieniu zawartym w Nowym Jorku dnia 15 sierpnia 1962 r. pomiędzy Republiką Indonezji a Królestwem Holandii, dotyczącym Zachodniej Nowej Gwinei (Zachodni Irian) (tzw. porozumienie nowojorskie), Akt Wolnego Wyboru miał zapewnić udział w głosowaniu wszystkim dorosłym mieszkańcom regionu, którzy mieli zadeklarować, czy chcą przyłączenia Nowej Gwinei Holenderskiej do Republiki Indonezji (art. XVIII porozumienia nowojorskiego) ${ }^{14}$. Jednakże rząd indonezyjski dopuścił do głosowania w referendum (Akt Wolnego Wyboru odbył się na przełomie lipca i sierpnia 1969 r.) zaledwie 1022 reprezentantów papuaskich, w większości wskazanych przez władze Indonezji ${ }^{15}$, którzy, jak później przyznawali, zostali poddani presji ze strony sił rządowych i zostali zmuszeni do zagłosowania zgodnego z zaleceniami rządu. Brak możliwości partycypacji wszystkich dorosłych mieszkańców w głosowaniu, a także sposób jego przeprowadzenia Papuasi uznali za wysoce niesprawiedliwy, sam zaś akt, na którego podstawie przeprowadzono referendum, określili jako Akt bez Wyboru, co podważyło w ich opinii jego legitymizację ${ }^{16}$.

Władze Indonezji uznały powyższe argumenty za bezzasadne, powołując się na poparcie ambasadora Ortiza Sanza (wysłannika Organizacji Narodów Zjednoczonych), który konsultował zasady głosowania nie tylko ze stroną indonezyjska, ale też ze społecznościami papuaskimi. Ponadto wyjaśniały, że ze względu na trudności logistyczne związane z dotarciem do wielu społeczności żyjących na geograficznie odległych terenach system powszechnego głosowania ,jeden człowiek, jeden głos" był w ówczesnym czasie nie do przeprowadzenia. W efekcie rząd indonezyjski stwierdził, że Papuasów reprezentowali demokratycznie wybrani przedstawiciele wyłonieni w zgromadzeniach doradczych przez lokalne społeczności, co spełniło warunek zawarty w art. XVIII porozumienia nowojorskiego ${ }^{17}$.

$13 \mathrm{~J}$. Elmslie, C. Webb-Gannon, P. King, Anatomy of an Occupation, The Indonesian Military in West Papua, s. 6, https://ro.uow.edu.au/sspapers/4061/ (dostęp: 30.04.2019).

14 J. Saltford, Akt wolnego wyboru 1969. Zaangażowanie ONZ w akt samostanowienia w Papui Zachodniej w latach 1968-1969, https://fwpcpoland.wordpress.com/akt-wolnego-wyboru-1969/ (dostęp: 30.04.2019). W artykule XVIIId porozumienia nowojorskiego nie ma objaśnień dotyczących międzynarodowych standardów.

15 Ibidem, s. 13.

16 J. Saltford, The United Nations, West Papua and the Act of Free-Choice: de-colonisation in action? [w:] Papers presented at the seminar on the Act of Free Choice, ed. P.J. Drooglever, Hague 2008, s. 66, http:// resources.huygens.knaw.nl/indonesischebetrekkingen1945-1969/DekolonisatieVanIndonesieEnHetZelfbeschikkingsrechtVanDePapoea/papers_pdf/papers (dostęp: 4.10.2019); B. Singh, West Irian and the Subarto Presidency: a perspective [w:] Papers presented at the seminar..., s. 89, http:// resources.huygens.knaw.nl/indonesischebetrekkingen1945-1969/DekolonisatieVanIndonesieEn HetZelfbeschikkingsrechtVanDePapoea/papers_pdf/papers (dostęp: 4.10.2019).

17 N. Viartasiwi, The politics of history in West Papua-Indonesia conflict, ,A Asian Journal of Political Science” 2018, vol. 26, no. 1, s. 147, https://www.offiziere.ch/wp-content/uploads-001/2018/07/ The-politics-of-history-in-West-Papua-Indonesia-conflict.pdf (dostęp: 4.10.2019). 
Pomimo przyłączenia Nowej Gwinei do Republiki Indonezji nacjonaliści papuascy nie zrezygnowali z dążeń do własnego państwa, czego wyrazem było założenie przez nich Ruchu Wolnej Papui (OPM - Organisasi Papua Merdeka) w 1965 r., który poprzez działania dyplomatyczne i militarne zamierzał doprowadzić do proklamowania niezależnej od Indonezji Wolnej Papui ${ }^{18}$. Dopiero upadek rządów Suharto dał rdzennym społecznościom nadzieję na uzyskanie ochrony ich praw. W wielu miejscach w Papui Zachodniej, takich jak Biak, Nabire, Sorong, Wamena i Timika, odbyły się pokojowe protesty ludności papuaskiej, jednakże zostały one brutalnie zdławione przez wojsko indonezyjskie. Pomimo rozpoczętego dialogu indonezyjskiego prezydenta Habibie z reprezentantami społeczności papuaskich zjednoczonych w organizację Foreri (Forum na rzecz Pojednania Społeczności Irianu Zwycięskiego - Forum Rekonsiliasi Rakyat Irian Jaya) trwały represje sił rządowych - policji i wojska w stosunku do demonstrujących papuaskich nacjonalistów. Definitywny koniec rozmów nastapił wówczas, gdy opozycja papuaska zażądała niepodległości dla Papui Zachodniej ${ }^{19}$.

Prezydentura następcy Habibiego - Abdurrahmana Wahida przyniosła otwarcie na ponowny dialog z nacjonalistami papuaskimi, rozpoczynając okres tzw. papuaskiej wiosny ${ }^{20}$. W wyniku tych rozmów prezydent Wahid zezwolił na wywieszenie flagi Papui Zachodniej - the morning star flag wraz z flaga indonezyjska w zwiazku z obchodami 38. rocznicy wywieszenia flagi papuaskiej, w których uczestniczyło około 800 tys. Papuasów ${ }^{21}$.

W lipcu 2000 r. zebrał się Drugi Kongres Ludności Papuaskiej, który zgromadził około 50 tys. Papuasów ze wszystkich regionów dawnego Irianu Zwycięskie$\mathrm{go}^{22}$. W trakcie kongresu została powołana Rada Papuaska (Dewan Papua), a także Prezydium Rady, które zaprosiło do swojego grona liderów Ruchu Wolnej Papui, w tym m.in. charyzmatycznego Theysa Eluaya. Uczestnicy kongresu przyjęli rezolucję, w której jednoznacznie odrzucono zarówno porozumienie nowojorskie, jak i wyniki głosowania przeprowadzonego w Akcie Wolnego Wyboru, powołując się przy tym na prawo międzynarodowe (art. 3 Powszechnej Deklaracji Praw Człowieka z 1948 r. oraz rezolucję Zgromadzenia Ogólnego ONZ nr 1514 (XV) dotyczącą przyznania niepodległości krajom i narodom kolonialnym z 1960 r. $)^{23}$, Konstytucję

18 Jednym z założycieli był Benny Wenda; zob. https://www.freewestpapua.org (dostęp: 1.10.2018).

19 Dynamics of conflict..., s. 8 .

20 Zob. więcej: https://www.theroadtohomefilm.com/background/ (dostęp: 30.04.2019).

21 J. Braitwaite, V. Braitwaite, M. Cookson, L. Dunn, Anomie and Violence..., s. 83.

22 Indonesia, Submission to the Universal Periodic Review of the United Nations Human Rights Council (third Cycle) $13^{\text {th }}$ session, on the right to self-determination, Papua Costumary Council, https://uprdoc.ohchr. org $/$ uprweb/downloadfile.aspx?filename $=3800 \&$ file $=$ EnglishTranslation (dostęp: 30.04 .2019$)$.

23 J. Anari, Comp. Eng, Debacle of Decolonization and Illegal Self Determination in West New Guinea Island, s. 19, https://mafiadoc.com/debacle-of-decolonization-and-illegal-self-determination_5a093b6b1723dd0b9e402cff.html (dostęp: 24.10.2019). 
Indonezji z 1945 r., a także nieustające dążenia Papuasów do uzyskania niepodległości. Prezydium Rady opowiedziało się też za pokojowymi negocjacjami z rządem Indonezji ${ }^{24}$.

W wyniku postulatów nacjonalistów papuaskich w 2001 r. została uchwalona specjalna autonomia dla prowincji Papua (Irian Zwycięski) na mocy ustawy o autonomii, która uwypukliła integralność prowincji z Republiką Indonezji (art. 1 pkt a) zostawiając władzy centralnej możliwość decydowania o polityce zagranicznej, bezpieczeństwie, systemie monetarnym i fiskalnym, religii i sądownictwie (art. 4 ust. 1) ${ }^{25}$. Mając na uwadze aspiracje Papuasów do własnej odrębności kulturowej, w ustawie zmieniono nazwę regionu z Irianu Zwycięskiego na Papuę (wstęp do ustawy, pkt k). W kwestii poszanowania ekspresji społecznej i kulturowej ustawa wprawdzie odniosła się do melanezyjskiego pochodzenia Papuasów oraz kultury, jaką reprezentuja, jednakże tylko w kontekście przynależności ludności papuaskiej do indonezyjskich grup etnicznych (wstęp do ustawy, pkt e); również papuaska flaga i hymn zostały uznane za kulturowe symbole regionu, nieoznaczające suwerenności i pozbawione kontekstu nacjonalistycznego (rozdz. 1, art. 1 pkt h). Przepisy ustawy wyraźnie więc przekreśliły aspiracje Papuasów do utworzenia niepodległego państwa.

Specjalna autonomia uwzględniła główne postulaty nacjonalistów papuaskich w kwestiach prawa do ziemi i bogactw naturalnych, praw politycznych, społecznych, gospodarczych i kulturowych. Ustawa odniosła się również do praw wspólnotowych (ulayat rights) i praw indywidualnych członków tradycyjnych społeczności adat ${ }^{26}$, które zgodnie z regulacjami powinny być respektowane. Jednakże nie przyznała możliwości odzyskania ziem, gdyż według ustawodawcy wiązałoby się to ze złamaniem prawa. Prowincja uzyskała $80 \%$ udziałów z przychodów z leśnictwa, z rybołówstwa i przemysłu wydobywczego oraz $70 \%$ udziałów z przychodów z wydobycia ropy naftowej i gazu. Ponadto przepisy ustawy zapewniały prawo do edukacji mieszkańcom Papui na wszystkich poziomach szkolnictwa oraz rozwój i postęp w tej dziedzinie, a także ochronę naturalnego środowiska przez państwo, gwarantując przy tym prawa i dobrobyt tej społeczności (art. 43, 44 ust. 3 i 4, art. 56-57, 64).

Pomimo ustanowienia specjalnej autonomii nacjonaliści papuascy twierdzili, że nie wszystkie przepisy były stosowane w praktyce, a władze Indonezji łamały prawo. Ponadto samodzielność Papuasów była ograniczona przez wpływy urzędników zasiadających w Dżakarcie, którzy dbali jedynie o swoje interesy w prowincji, a przychody z zasobów bogactw naturalnych trafiały do elity wojskowej. $\mathrm{Na}$ wielu szczeblach lokalnej administracji panowały korupcja i nepotyzm, a w prowincji kwitło nielegalne wydobycie surowców naturalnych. Słabość struktur państwa oraz po-

${ }^{24}$ J. Braitwaite, V. Braitwaite, M. Cookson, L. Dunn, Anomie and Violence..., s. 84, 85.

25 O. Mote, Special Autonomy...

26 Słowo adat pochodzi z języka arabskiego i oznacza przyzwyczajenie lub zwyczaj. W. Kowalak, Biuletyn misjologiczno-religioznawnsy, „Collectanea Theologica” 1978, nr 48/4, s. 171. 
wszechne zaniedbania były jedną z przyczyn niezadowolenia mieszkańców, co podtrzymywało długoletni konflikt pomiędzy ludnością rdzenną a władzami państwa ${ }^{27}$.

Opozycja papuaska nie zrezygnowała z dążeń do utworzenia własnego państwa, gdyż w 2014 r. zawiązała Zjednoczony Ruch Wolnej Papui (United Liberation Movement for West Papua - ULMWP), który zgrupował dotychczas rozproszone środowiska nacjonalistów papuaskich. Mając wsparcie wielu ugrupowań papuaskich, lider ULMWP Benny Wenda w styczniu 2019 r. wystosował petycję do ONZ, w której wezwał do wsparcia referendum niepodległościowego dla Papui Zachodniej ${ }^{28}$. ULMWP zostało też zaakceptowane jako obserwator w Subregionalnej Organizacji Państw Kultury Melanezyjskiej (Melanesian Spearhead Group - MSG), mającej na celu kształtowanie zgodnej polityki gospodarczej ${ }^{29}$. Stworzenie wspólnego parasola dla grup opozycyjnych miało też na celu zaprezentowanie silnego stanowiska wobec Indonezji, która jako członek stowarzyszony MSG umniejszała rolę aktywistów papuaskich, twierdząc, że ich głosy są mało znaczące. Ponadto osiąnięcie statusu obserwatora dla ugrupowania nacjonalistów papuaskich dało im szansę, by zwrócić uwagę społeczności międzynarodowej na łamanie praw człowieka w Papui Zachodniej przez indonezyjskie władze ${ }^{30}$.

Raporty organizacji pozarządowych przesyłane do Rady Praw Człowieka ONZ wskazywały na liczne przypadki arbitralnych aresztowań ${ }^{31}$, tortur ${ }^{32}$, a nawet morderstw $^{33}$, do których dochodziło przy okazji protestów społecznych w Papui Zachodniej. Zaznaczono w nich, że wiele naruszeń praw człowieka nie było badanych, a organy ścigania nie inicjowały postępowań pomimo łamania praw człowieka przez służby bezpieczeństwa ${ }^{34}$.

27 Przykładem tego są interesy wojskowych związane ze spółką Freepont oraz nielegalna wycinka lasów czy połowy ryb chronione przez indonezyjskie siły wojskowe. J. Braitwaite, V. Braitwaite, M. Cookson, L. Dunn, Anomie and Violence..., s. 101.

28 Petycję podpisało 1,8 mln osób; zob. United Liberation Movement for West Papua (ULMWP). Free Papua Movement. Organisasi Papua Merdeka (OPM), https://www.globalsecurity.org/military/ world/para/papua.htm (dostęp: 4.10.2019).

29 https://www.msgsec.info/about-msg/ (dostęp: 4.10.2019).

30 S. Philpott, This stillness, this lack of incident: making conflict visible in West Papua, „Critical Asian Studies" 2018, vol. 50, issue 2, s. 12, https://doi.org/10.1080/14672715.2018.1445537 (dostęp: 4.10.2019).

31 Organizacja Pasifika zaalarmowała o wzroście arbitralnych aresztowań ze 183 w 2014 r. do 1783 w 2016 r. Zob. Indonesia, submission...

32 Specjalista od konfliktu w Papui Zachodniej - Budi Hernawan udokumentował 431 przypadków tortur w latach 1963-2010; zob. J. Elmslie, C. Webb-Gannon, A Slow-Motion Genocide: Indonesian Rule in West Papua, „Griffith Journal of Law \& Human Dignity” 2013, vol. 1(2), s. 150.

33 Jim Elmslie i Camellia Webb-Gannon podają liczbę około 500 tys. Papuasów zabitych przez indonezyjskie sily rządowe w latach 1962-2013; zob. ibidem.

34 The Human Rights situation in West Papua. UNPO submission to the Human Rights Council's Expert Mechanism on the Rights of Indigenous Peoples, s. 6, https://unpo.org/overview/1/5/6 (dostęp: 13.05.2019). 
Biorąc pod uwagę drugą stronę sporu, czyli postawę władz Indonezji, należy zauważyć, że kolejne rządy indonezyjskie konsekwentnie traktowały działania Papuasów jako przejawy separatyzmu podważające integralność państwa ${ }^{35}$. Walka sił rządowych z nacjonalistami papuaskimi toczyła się jednak za zasłoną, albowiem już od 1993 r. władze Indonezji ograniczały lub uniemożliwiały wjazd na teren Papui Zachodniej dziennikarzom zagranicznym, a także członkom organizacji pozarządowych i organizacji międzynarodowych, takich jak np. UNHCR ${ }^{36}$. Ponadto w $2018 \mathrm{r}$. Indonezja nie przedłużyła stałego zaproszenia dla wszystkich specjalnych sprawozdawców Rady Praw Człowieka ONZ, co utrudniło obiektywną ocenę sytuacji międzynarodowym ekspertom i badaczom tematu ${ }^{37}$.

Rząd Republiki Indonezji uważał jednak, że w związku z naruszeniami praw człowieka przez funkcjonariuszy państwa prowadził działania mające na celu promowanie praw człowieka w Papui Zachodniej. Działalność rządowa w zakresie ochrony praw człowieka była też poddawana ocenie społeczności międzynarodowej i niezależnych ekspertów z dziedziny praw człowieka w ramach mechanizmu Powszechnego Okresowego Przeglądu w Radzie Praw Człowieka ONZ. W związku z tym rząd indonezyjski był zobligowany do zabrania głosu w sprawach naruszeń praw człowieka przedstawionych przez organizacje pozarządowe, takie jak: Aliansi Masyarakat Adat Nusantara (AMAN), czyli organizację zrzeszającą rdzenne społeczności w Indonezji czy międzynarodową organizację Amnesty International, a także musiał odnieść się do rekomendacji ze strony państw członkowskich $^{38}$. Przykładem takiej inicjatywy było powołanie specjalnego zespołu podlegającego Ministerstwu Spraw Wewnętrznych, który podjął się badania poszczególnych spraw dotyczących łamania praw człowieka na tym terytorium. Wprowadzono również system szkoleń dla policji na temat przestrzegania praw człowieka, w którym funkcję prelegentów pełnili przedstawiciele Międzynarodowego Komitetu Czerwonego Krzyża. Jeśli chodzi o niedopuszczenie do wjazdu niezależnych ekspertów do prowincji, to władze indonezyjskie poinformowały Radę Praw Człowieka ONZ, że zaimplementowały standardy dotyczące wizyt dziennikarzy oraz organizacji pozarządowych, które mają im umożliwiać pracę w obu prowincjach ${ }^{39}$.

35 J. Elmslie, C. Webb-Gannon, P. King, Anatomy of an Occupation..., s. 3.

36 Dynamics of conflict..., s. 11.

37 https://spinternet.ohchr.org/_Layouts/SpecialProceduresInternet/StandingInvitations. aspx (dostęp: 30.04.2019).

38 Raporty dotyczące Republiki Indonezji w ramach Powszechnego Przeglądu Okresowego Rady Praw Człowieka ONZ zob. https://www.ohchr.org/EN/HRBodies/UPR/Pages/IDIndex.aspx (dostęp: 24.10.2019).

39 Report A/HRC/WG.6/27/IDN/1. 


\section{Wyzwania prawne}

Konflikt w Papui Zachodniej dotyczy nie tylko kwestii samostanowienia Papuasów, lecz kompleksowo wiąże się z systemem ochrony praw ludności rdzennej, jaki funkcjonuje w Republice Indonezji. Chociaż Indonezja jest sygnatariuszem Deklaracji Organizacji Narodów Zjednoczonych Ochrony Praw Ludności Rdzennej z 13 września 2007 r., zaadaptowanej przez Zgromadzenie Ogólne ONZ, co moralnie i politycznie zobowiązuje władze państwa do przestrzegania praw tych społeczności, to sam rząd uważa, że pojęcie rdzennej ludności używane przez ONZ jest nieadekwatne do sytuacji w Indonezji, ponieważ wszystkich Indonezyjczyków z wyjątkiem etnicznych Chińczyków uznają za społeczność rdzenną ${ }^{40}$.

Stanowisko rządu indonezyjskiego jest jednak sprzeczne z Konstytucją Republiki Indonezji z dnia 18 sierpnia 1945 r., która w art. 18B pkt 2 i art. 28I pkt 3 wyróżnia rdzenne społeczności i odnosi się do ochrony ich praw, a także z wieloma ustawami prawa krajowego, w których funkcjonuja tradycyjne społeczności rdzenne zwane masyarakat adat lub masyarakat bukum adat ${ }^{41}$. Z postawą rządu nie zgadza się też organizacja AMAN, która uważa za ludność rdzenną społeczności zamieszkałe od pokoleń w Indonezji, kierujące się zasadami życia społecznego według tradycyjnych praw adat oraz posiadające własne instytucje zorganizowane zgodnie z regułami ddatu $^{42}$. Fundamentalnym elementem definicji ludności rdzennej przyjętej przez AMAN jest samoidentyfikacja społeczności rdzennych należących do organizacji (warunek ujęty również w definicji ludności rdzennej zawartej w art. 1 pkt 2 Konwencji Nr 169 Międzynarodowej Organizacji Pracy dotyczącej ludności tubylczej i plemiennej w krajach niezależnych uchwalonej 7 czerwca 1989 r. w Genewie) ${ }^{43}$.

40 Report A/HRC/21/7/Add.1 Human Rights Council Working Group on the Universal Periodic Review Twenty-first session, pkt 6.3, https://lib.ohchr.org/HRBodies/UPR/_layouts/15/ WopiFrame.aspx?sourcedoc $=/ \mathrm{HRBodies} / \mathrm{UPR} /$ Documents $/$ session13/IN/A_HRC_21_7_ Add.1_Indonesia_E.doc\&action=default\&DefaultItemOpen=1 (dostęp: 4.10.2019).

${ }^{41}$ The Asia Indigenous Peoples Pact 'Joint Stakeholders' Submission on The Situation of Human Rights of Indigenous Peoples in Indonesia. Submission Prepared for $3^{\text {rd }}$ Cycle of Universal Periodic Review of Indonesia, s. 7, https://www.forestpeoples.org/sites/fpp/files/publication/2016/09/indonesiaamanaippupr3rdcyclefinal.pdf (dostęp: 30.04.2019).

42 Joint Stakeholders' Submission on The Situation of Human Rights of Indigenous Peoples in Indonesia. Submission Prepared for $3^{\text {rd }}$ Cycle of Universal Periodic Review of Indonesia $27^{\text {th }}$ Session of the Human Rights Council (Apr-May 2017), http://www.aman.or.id/wp-content/ uploads/2016/09/INDONESIA_AMAN_AIPP_UPR_3rdCycle.pdf (dostęp: 10.11.2018); M.A. Safitri, R.E. Bosko, Indigenous peoples/ethnic minorities and poverty reduction. Indonesia, Manila 2002, s. 5.

43 M.A. Safitri, R.E. Bosko, Indigenous peoples..., s. 6. 
Należy jednak zauważyć, że w prawie indonezyjskim istnieją też przepisy ograniczające prawa ludności rdzennej, co jest wynikiem obowiązywania regulacji sprzed zmiany ustrojowej, która nastąpiła po upadku rządów prezydenta Suharto. Przykładem tego są obowiązujacce do dzisiaj ustawa agrarna i ustawa dotycząca lasów. W 1960 r. została wprowadzona ustawa agrarna nr 5 dotycząca prawa własności zie$\mathrm{mi}^{44}$, w której ziemię, wodę, przestrzeń oraz bogactwa naturalne uznano za własność narodu indonezyjskiego (art. 1), natomiast państwo jako reprezentant narodu miało sprawować kontrolę nad własnością prywatną (art. 2). Ustawa w art. 1-3 i art. 5 nawiązywała wprawdzie do pojęcia praw wspólnotowych adat, istotnych dla ludności rdzennej, jednakże miały być one przestrzegane pod warunkiem, że społeczności te nadal istnieją $\mathrm{i}$ że ich prawa nie są w konflikcie $z$ interesem narodowym oraz innymi przepisami nadrzędnymi w stosunku do lokalnych regulacji ${ }^{45}$. W objaśnieniach do ustawy agrarnej prawa wspólnotowe zostały zdefiniowane jako „dotyczące wszystkich Indonezyjczyków”, pomijając wcześniejsze odniesienie do społeczności praw adat, co spowodowało rozbieżne interpretacje tego artykułu, a w praktyce utrudniło dochodzenie swoich praw przez ludność rdzenną ${ }^{46}$. W rezultacie ustawa agrarna na skutek braku przepisów dotyczących uznania praw wspólnotowych, niejasnych kryteriów wywłaszczeniowych oraz nadrzędności interesu narodowego nad prawami własnościowymi zapoczątkowała proces wywłaszczania społeczności praw adat oraz marginalizację ich praw ${ }^{47}$.

W 1967 r. władze indonezyjskie wprowadziły ustawę dotyczącą lasów (ustawa nr 5 z 1967 r.), w myśl której rząd poniósł odpowiedzialność za planowe gospodarowanie terenami leśnymi dla najlepszego ich wykorzystania w gospodarce Indonezji. Ustawa dała uprawnienia władzy centralnej, która miała decydować o kwalifikacji i użytkowaniu lasu zgodnie z szeroko pojętym interesem publicznym (art. 4). Regulacja ta objęła około 120-140 mln ha lasów Indonezji, które od tej pory stały się własnościa państwową ${ }^{48}$. W praktyce władze przekształcały tereny leśne w ziemie rolne i przeznaczały je do uprawy dochodowej palmy oleistej. Ustawa miała wpływ

44 S. Prokurat, Prawne i ekonomiczne aspekty obrotu ziemiq w Indonerjii, s. 7, https://depot.ceon.pl/ handle/123456789/2415 (dostęp: 15.11.2018).

${ }^{45}$ Koncept praw wspólnotowych (bak ulayat) został upowszechniony jako termin dotyczący ogólnie pojętych praw wspólnotowych do własności ziemi; zob. Legalising Land Rights. Local Practices, State Responses and Tenure Security in Africa, Asia and Latin America, eds. J.M. Ubink, A.J. Hoekema, W.J. Assies, Leiden 2009, s. 498.

46 Ibidem, s. 500.

47 B. Hauser-Schäublin, Adat and Indigeneity in Indonesia. Culture and Entitlements between Heteronomy and Self-Ascription, „Götingen Studies in Cultural Property” 2013, vol. 7, s. 48.

48 Prawdopodobnie jednak liczby te są mniejsze, ponieważ rząd zaliczał do lasów także ziemie wyeksploatowane i niezalesione; zob. D. Bachriadi, M.A. Sardjono, Conversion or Occupation? The Possibility of Returning Local Communties' Control Over Forest Lands In Indononesia, 25.11.2005, s. 1-4, https://pdfs.semanticscholar.org/8d23/3731602329c047840741a6e6b67ea8772a54.pdf (dostęp: 30.04.2019). 
na społeczności rdzenne żyjące z bogactw lasu, gdyż znacząco ograniczała ich prawa do czerpania z nich, dając im jedynie możliwość zbierania obumarłych drzew ${ }^{49}$. W 1999 r. wprowadzono ustawę, która zastapiła tę z 1967 r., przyznając państwu prawo do kontroli nad wszystkimi zasobami leśnymi (art. 4 ust. 1). W ustawie znalazł się przepis odnoszący się do praw ludności rdzennej do lasu, z zastrzeżeniem, że społeczności te funkcjonuja zgodnie $\mathrm{i}$ ich interesy nie są sprzeczne $\mathrm{z}$ interesem państwa (art. 4 ust. 3).

W praktyce zarówno w przypadku ustawy agrarnej, jak i ustawy dotyczącej lasów oba warunki utrudniają odzyskanie praw ludności do tradycyjnych terenów. Wiąże się to z problemami w zakwalifikowaniu danej grupy etnicznej do rdzennych społeczności, co leży w kompetencjach lokalnej władzy, a także z wykazaniem priorytetowego charakteru ich interesów. Dodatkową komplikacją jest różnorodność tradycyjnych praw własności związana z wzorami prawa spadkowego oraz użytkowania ziemi, które w zależności od tradycji mogły być dziedziczone po linii ojca, matki lub innych krewnych ${ }^{50}$. Sposób użytkowania ziemi zależał również od kultywowanych obyczajów i w związku z tym mógł być indywidualny lub wspólny ${ }^{51}$.

W związku z wzajemnie się wykluczającymi regulacjami prawnymi od 2009 r. w parlamencie indonezyjskim trwają prace nad harmonizacją ustaw dotyczacych ochrony praw tradycyjnych społeczności adat w ramach przygotowywania projektu regulacji dotyczącej uznania i ochrony praw rdzennej ludności (The Bill on Recognition and Protection of the Rights of Indigenous Peoples - PPHMA). Projekt ten został także włączony do Narodowego Programu Legislacyjnego na lata 2015-2019, co wiąże się z nadzieją dla społeczności rdzennych, że ich problemy zostały nie tylko zauważone przez władze państwa, ale też ich prawa będą należycie chronione ${ }^{52}$.

Optymistycznym wydarzeniem dla aktywistów działających na rzecz ochrony praw ludności rdzennej było również orzeczenie Sądu Konstytucyjnego Republiki Indonezji (MK 35/PUU-X/2012), w którym stwierdzono, że lasy tradycyjnie zamieszkałe przez rdzenną ludność nie są własnością państwa. Sąd, powołując się na ustawę dotyczącą lasów nr 41 z 1999 r., rozgraniczył lasy państwowe od lasów tradycyjnie zamieszkałych przez rdzenną ludność, a tym samym wskazał na możliwość odzyskania spornych terenów przez lokalne społeczności ${ }^{53}$.

\footnotetext{
49 Ibidem, s. 1-4.

50 Legalising Land Rights..., s. 501-503.

51 Heritage and Rights of Indigenous Peoples. Patrimonio y Derechos de Los Pueblos Indigenas, eds. M.M. Castillo, A. Strecker, Leiden 2017, s. 122.

52 The Asia Indigenous Peoples Pact...

53 N.F. Rachman, H. Masalam, The trajectory of indigeneity politics against land dispossession in Indonesia, „Sriwijaya Law Review” 2019, vol. 3, issue 2, s. 107, http://journal.fh.unsri.ac.id/index.php/ sriwijayalawreview (dostęp: 4.10.2019).
} 
W 2014 r. Komisja Praw Człowieka Komnas HAM, kierując się orzeczeniem Sądu Konstytucyjnego Republiki Indonezji (MK 35/PUU-X/2012), zainicjowała Narodowe dochodzenie w sprawie praw rdzennej ludności do ziemi i lasu (National Inquiry into Indigenous Peoples Rights on their Territories in the Forest Zone). Badanie polegało na zbieraniu informacji o spornych terenach od przedstawicieli społeczności rdzennych i zawierało m.in. analizę przypadków, przesłuchania świadków oraz przeprowadzenie dialogu z rządem i spółkami handlowymi. Dochodzenie objęło siedem regionów, w tym Papuę Zachodnią, dając nadzieję rdzennej ludności na realne zainteresowanie państwa kwestiami spornymi dotyczącymi prawa własności ${ }^{54}$.

\section{Wyzwania ekonomiczne}

Kilkudziesięcioletnie pozbawianie rdzennej ludności praw do ziemi i bogactw naturalnych spowodowało jej zubożenie. Przykładem na to jest sytuacja w Papui Zachodniej, w której konflikt rządu ze społecznością rdzenną, a także zmieniające się regulacje spowodowały spadek inwestycji, w wyniku czego ta część Indonezji charakteryzuje się najniższymi wskaźnikami rozwoju społecznego (HDI - Human Development Index) w państwie ${ }^{55}$. W wielu miejscach odnotowano brak dostępu do elektryczności, bieżącej wody, urządzeń sanitarnych i infrastruktury, a na terenach rolnych nie prowadzono nowoczesnych metod uprawy ziemi, które pomogłyby zaspokoić potrzeby mieszkańców. W Papui Zachodniej pracowała niewystarczająca liczba nauczycieli, co skutkowało niskim poziomem alfabetyzacji ${ }^{56}$. Ponadto w związku z utrudnionym dostępem do opieki medycznej lub jego brakiem przewidywana długość życia ludności papuaskiej jest najniższa ze

54 Ibidem, s. 107-111; zob. też: S. Moniaga, E. Soeprapto, H. Kartodihardjo, S.T. Situmorang, National Inquiry into Indigenous Peoples Rights on their Territories in the Forest Zone. Summary of Findings and Recommendations for Improvement of the Law and Policy Concerning Respect, Protection, Compliance and Remedy Relating to the Human Rights of Indigenous Peoples over their Territories within the Forest Zone, https://www.forestpeoples.org/sites/default/files/publication/2016/04/komnas-ham-nationalinquiry-summary-apr2016.pdf (dostęp: 4.10.2019).

55 W 2017 r. Papua Zachodnia miała 62,99 HDI, a Papua 59,09 HDI; zob. Indeks Pembangunan Manusia menurut Provinsi, 2010-2018 (Metode Baru), https://www.bps.go.id/linkTableDinamis/ view/id/1211 (dostęp: 30.04.2019).

${ }^{56}$ J. Braitwaite, V. Braitwaite, M. Cookson, L. Dunn, Anomie and Violence..., s. 52. W Papui Zachodniej w 2010 r. 32\% dzieci poniżej 15. roku życia było analfabetami; zob. Fighting Illiteracy in Indonesia's Papua region, http://www.id.undp.org/content/indonesia/en/home/ourwork/ povertyreduction/successstories/fighting-illiteracy-in-indonesias-papua-region.html (dostęp: 30.04.2019). 
wszystkich prowincji Indonezji, a choroby zakaźne, takie jak malaria, denga czy HIV, stały się endemiczne ${ }^{57}$.

Mając na uwadze sytuację w Papui Zachodniej, a także w innych trudno dostępnych regionach, rząd indonezyjski zainicjował program Rozwijanie Indonezji na peryferiach, polegający na polepszaniu warunków życia ludności mieszkającej na odległych geograficznie terenach. W ramach projektu zostały rozdystrybuowane świadczenia społeczne dla około $15,5 \mathrm{mln}$ gospodarstw domowych i około 19,7 mln studentów ${ }^{58}$. W 2014 r. rząd indonezyjski wprowadził narodowy system ubezpieczeń zdrowotnych Jaminan Kesehatan Nasional (JKN), mający na celu umożliwienie dostępu do podstawowych usług medycznych każdemu Indonezyjczykowi, zwłaszcza tym, którzy do tej pory ze względów finansowych byli wykluczeni z możliwości korzystania z opieki medycznej ${ }^{59}$.

Punktem zapalnym pomiędzy ludnością papuaską a rządem indonezyjskim była też dewastacja naturalnego środowiska związana z tworzeniem wielohektarowych plantacji palmy oleistej, przemysłem wydobywczym oraz drzewnym. Działania te skutkowały zanieczyszczeniem wody oraz erozją gleb. Poważnie też naruszały lokalne ekosystemy. Inwestycje były prowadzone przez spółki powiązane z władzami państwa, które poprzez nadmierną eksploatację terenów leśnych pozbawiały dostępu do zasobów lasu mieszkającą tam ludność rdzenną ${ }^{60}$. Deforestacja lasów i monokultura rolnicza związana z uprawą palmy oleistej stały się zagrożeniem dla dobrostanu tropikalnych lasów deszczowych w całej Indonezji.

W związku z tym problemem władze państwa zdecydowały się na implementację Programu dotyczącego redukcji emisji gazu cieplarnianego spowodowanego wylesianiem (Reducing emissions from deforestation and forest degradation REDD). Parlament uchwalił dekrety ministerialne dopuszczające program pilotażowy, nakreślające mechanizmy niezbędne do redukcji deforestacji lasów oraz monitorujące działania rządu. REDD obejmuje także ochronę bioróżnorodności, istotnej dla rdzennej ludności korzystającej z zasobów lasu ${ }^{61}$. Działania te wpisują

57 Report A/HRC/WG.6/27/IDN/3 Human Rights Council Working Group on the Universal Periodic Review Twenty-seventh session 1-12 May 2017, pkt 58, https://documents.un.org/ prod/ods.nsf/xpSearchResultsM.xsp (dostęp: 30.04.2019). Choroby endemiczne w terminologii medycznej oznaczają choroby, które utrzymują się przez długi czas na danym obszarze.

58 Report A/HRC/36/7, Human Rights Council Working Group on the Universal Periodic Review Thirty-six session 11-29 September 2017, https://documents-dds-ny.un.org/doc/UNDOC/GEN/G17/192/60/PDF/G1719260.pdf?OpenElement (dostęp: 4.10.2019).

59 The Republic of Indonesia Health System Review, eds. K. Hort, W. Patcharanarumol, „Health Systems in Transition" 2017, vol. 7, no. 1, https://apps.who.int/iris/bitstream/handle/10665/ 254716/9789290225164-eng.pdf (dostęp: 4.10.2019).

${ }_{60}$ Report A/HRC/WG.6/27/IDN/3, s. 18, 20.

${ }^{61}$ J. Caldecott, A. Mahaningtyas, B. Howard, D. Williams, P. Lincoln, Third independent review of the Indonesia-Norway cooperation on reducing greenhouse gas emission from REDD+. Final Report. 28 September 2018, s. 13-18, https://www.cmi.no/publications/6663-third-independent-review-of-the- 
się w postanowienia Konwencji o różnorodności biologicznej sporządzonej w Rio de Janeiro dnia 5 czerwca 1992 r., której stroną jest Indonezja ${ }^{62}$.

\section{Nadzieja na zmianę}

W związku z wyzwaniami politycznymi, prawnymi i ekonomicznymi rząd indonezyjski podjął działania mające na celu ochronę praw rdzennej ludności papuaskiej, dające nadzieję na pokojowe zakończenie konfliktu w Papui Zachodniej. Po wieloletnich protestach nacjonalistów papuaskich w sprawie ochrony praw rdzennych mieszkańców prowincji ich prawa zostały umocowane w specjalnej ustawie o autonomii. Rekomendacje państw członkowskich oraz niezależnych ekspertów Rady Praw Człowieka w ONZ, a także bieżące monitorowanie sytuacji ludności rdzennej w obszarze ochrony praw człowieka przez agencje ONZ zajmujące się tą tematyką spowodowały, że rząd Indonezji wprowadził regulacje lepiej chroniące prawa społeczności papuaskiej. W wyniku presji społeczności międzynarodowej władze indonezyjskie podjęły wiele aktywności mających na celu wzmocnienie norm prawnych oraz standardów instytucjonalnych. Istotnym elementem pozostaje jednak zmiana paradygmatu dotyczącego określenia rdzennej ludności na terytorium Indonezji, którą prezentuja jej władze. Zaakceptowanie definicji ludności rdzennej wyrażonej w Konwencji Nr 169 Międzynarodowej Organizacji Pracy z 1989 r. wyznaczyłoby ramy postępowania rządu indonezyjskiego w procesie harmonizacji prawa dotyczącego ochrony praw ludności rdzennej. Kontynuacja monitoringu prowadzonego przez wewnętrzne instytucje państwowe, a także dalsza współpraca w ramach struktur ONZ działających na rzecz praw człowieka, w tym przedłużenie stałych zaproszeń dla niezależnych ekspertów z Rady Praw Człowieka, są niezbędne do wprowadzenia systemowej zmiany w dziedzinie ochrony praw ludności rdzennej w Indonezji.

\section{SUMMARY}

\section{THE CHALLENGES TO PROTECT THE RIGHTS OF INDIGENOUS PEOPLES IN WEST PAPUA}

The purpose of the article is to present the political, legal and economic challenges which are facing the authorities of the Republic of Indonesia in the province of Papua and West Papua.

indonesia-norway (dostęp: 9.09.2019), także ustawy P68/2008, P30/2009, P20/2012 dostępne na https://theredddesk.org/countries/indonesia (dostęp: 10.10.2019).

${ }^{62}$ https://www.cbd.int (dostęp: 9.09.2019). 
An armed conflict is going on in this area between successive Indonesian governments and Papuan nationalists, which involves demands regarding the protection of the rights of indigenous peoples. Since 2001, a law on special autonomy has been in force in both provinces, which grants a number of rights to the inhabitants of this territory. However, Papuan nationalists say that this law is not implemented. The Indonesian authorities disagree with this opinion. The article presents both of these positions, as well as specific actions of the Indonesian government to improve the protection of the rights of indigenous peoples, which the author assumes are the result of pressure from the international community. 